\section{Preclinical Cushing's Syndrome Associated with Non-Islet Cell Tumor Hypoglycemia; An Additional Report}

Key words: preclinical Cushing's syndrome, non-islet cell tumor hypoglycemia, insulin-like growth factor II

We have recently reported a case of preclinical Cushing's syndrome associated with severe hypoglycemia (1). We speculated that hypoglycemia in that case could have been due to disorders of the hypothalamo-pituitary-adrenal axis. But further analysis of that case indicated that the severe hypoglycemia might be caused by non-islet cell tumor hypoglycemia (NICTH) producing insulin-like growth factor II (IGF-II).

A 52-year-old man with Chilaiditi syndrome and severe mental retardation was admitted to Kanagawa Rehabilitation Hospital for examination of malnutrition and severe hypoglycemia. He was finally diagnosed as preclinical Cushing's syndrome as previously reported (1). Briefly, his first manifestation was weight loss and leg edema due to hypoalbuminemia. Subsequently, he suffered hypoglycemic coma and was admitted to our hospital on March 29, 2001. His physical symptoms and endocrinological data, except for plasma adrenocorticotropin (ACTH) and serum cortisol levels $(6 \mathrm{pg} / \mathrm{ml}$ and $41.4 \mu \mathrm{g} / \mathrm{dl}$ together with plasma glucose 51 $\mathrm{mg} / \mathrm{dl}$ on the next morning of admission, respectively) seemed to be compatible with isolated ACTH deficiency and replacement of hydrocortisone $(10 \mathrm{mg} /$ day $)$ was initiated. However, further endocrinological examinations revealed autonomic cortisol secretion and finally, this patient was diagnosed as preclinical Cushing's syndrome in spite of successful hydrocortisone replacement. During the follow-up period, his general condition became unstable after the dose of hydrocortisone decreased to $5 \mathrm{mg} /$ day due to the diagnosis of preclinical Cushing's syndrome. Thereafter, he manifested dehydration because of severe diarrhea, which was improved by oral administration of hydrocortisone $(10 \mathrm{mg} /$ day $)$. Then, we examined the possible expression of IGF-II to rule out NICTH using a serum sample obtained during cessation of hydrocortisone. Western immunoblot analysis (2) of the patient's serum showed the big form of IGF-II in addition to authentic IGF-II (7.5 kDa) (Fig. 1, lane 3), suggesting the existence of IGF-II-producing tumor. Although a causative tumor was detected in the left adrenal gland $(3 \mathrm{~cm}$ in diameter) by the follow-up computed tomography scan on May 30 , 2003 , this patient has been conservatively followed up with oral hydrocortisone replacement because of his mental status and refusal of adrenalectomy by his family.
NICTH was characterized by overexpression of IGF-II in non-islet tumors, leading to hypoglycemia with suppressed serum insulin levels and big IGF-II in sera $(2,3)$. The present case was diagnosed as preclinical Cushing's syndrome due to autonomic cortisol secretion and in addition, expression of IGF-II (Fig. 1), which could be modulated by hydrocortisone replacement $(3,4)$, strongly indicates that the present case may also be complicated by IGF-II-producing tumor. So, we hypothesize that NICTH may be related to severe hypoglycemia in the present case, although Lloyd et al (5) suggested that the expression and production of IGF-II could not accurately predict patients with clinical evidence of hypoglycemia. But the definite reason that even autonomic secretion of cortisol could not compensate for severe hypoglycemia is still unknown. Finally, replacement with hydrocortisone may be a useful choice to treat cases similar to the present case.

\section{Keiichi IKedA, Masato MizuguchI, Hiraku YoshidA, Katsuyoshi ToJo*, Naomi HIZUKA***, Naoko TAJIMA* and Tatsuo HosoYA**}

From the Department of Internal Medicine, Kanagawa Rehabilitation Hospital, Atsugi, *the Division of Diabetes and Endocrinology and **the Division of Nephrology and Hypertension, the Department of Internal Medicine, Jikei University School of Medicine, Tokyo and ***the Department of Medicine II, Tokyo Women's Medical University, Tokyo Received for publication June 6, 2003; Accepted for publication August 14, 2003

Reprint requests should be addressed to Dr. Katsuyoshi Tojo, the Division of Diabetes and Endocrinology, Department of Internal Medicine, Jikei University School of Medicine, 3-25-8 Nishishinbashi, Minato-ku, Tokyo $105-8461$

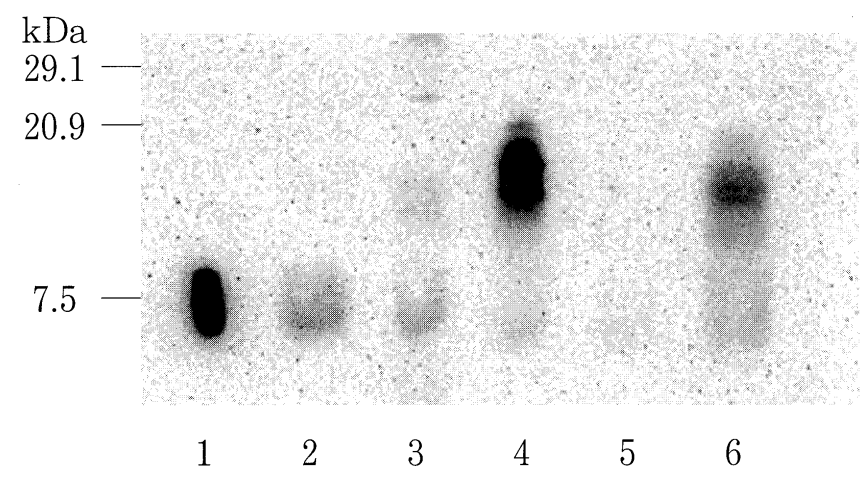

Figure 1. Western immunoblot analysis of serum big form of insulin-like growth factor (IGF)-II. Lane 1; human IGF-II, Lane 2; serum from a healthy person, Lane 3; serum from the present case, Lanes 4, 6; serum from patients with non-islet cell tumor hypoglycemia, Lane 5; serum from a patient of hypoglycemia (unknown cause). 


\section{References}

1) Ikeda K, Mizuguchi M, Ebisawa T, et al. Preclinical Cushing's syndrome presenting with isolated adrenocorticotropin (ACTH) deficiency-like manifestations and severe hypoalbuminemia without overt adrenal masses in a patient with Chilaiditi syndrome and mental retardation. Intern Med 42: 410-415, 2003.

2) Hizuka N, Fukuda I, Takano K, Okubo Y, Asakawa-Yasumoto K, Demura H. Serum insulin-like growth factor II in 44 patients with non- islet cell tumor hypoglycemia. Endocr J 45 (Suppl): S61-S65, 1998.

3) Baxter RC. The role of insulin-like growth factors and their binding proteins in tumor hypoglycemia. Horm Res 46: 195-201, 1996.

4) Teale JD, Marks V. Glucocorticoid therapy suppresses abnormal secretion of big IGF-II by non-islet cell tumors inducing hypoglycemia (NICTH). Clin Endocrinol 49: 491-498, 1998.

5) Lloyd RV, Erickson LA, Nascimento AG, Kloppel G. Neoplasms causing nonhyperinsulinemic hypoglycemia. Endocr Pathol 10: 291-297, 1999. 